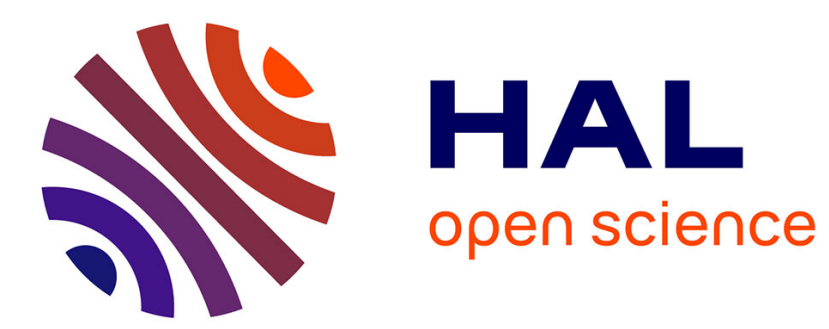

\title{
The Tabula in the Collège de Sorbonne and the discovery of the 1529 Bomberg Siddur
}

Judith Kogel

\section{To cite this version:}

Judith Kogel. The Tabula in the Collège de Sorbonne and the discovery of the 1529 Bomberg Siddur. Zutot: Perspectives on Jewish Culture, 2021, 18, pp.48-64. 10.1163/18750214-BJA10008 . halshs03079107

\section{HAL Id: halshs-03079107 https://shs.hal.science/halshs-03079107}

Submitted on 30 Dec 2021

HAL is a multi-disciplinary open access archive for the deposit and dissemination of scientific research documents, whether they are published or not. The documents may come from teaching and research institutions in France or abroad, or from public or private research centers.
L'archive ouverte pluridisciplinaire HAL, est destinée au dépôt et à la diffusion de documents scientifiques de niveau recherche, publiés ou non, émanant des établissements d'enseignement et de recherche français ou étrangers, des laboratoires publics ou privés. 


\title{
The Tabula in the Collège de Sorbonne and the Discovery of the 1529 Bomberg Siddur
}

\author{
Judith Kogel \\ Senior Researcher, Institut de recherche et d'histoire des textes (IRHT) - Centre national de la \\ recherche scientifique (CNRS), Paris, France \\ Judith.kogel@irht.cnrs.fr
}

\begin{abstract}
Interest was aroused recently concerning a booklet of 28 folios entitled Tabula in universum indicans libros singularum disciplinarum. Formerly considered a 17thcentury catalogue, it actually reflects the contents of the library of the Collège de Sorbonne in the mid-16th century. A project, directed by Gilbert Fournier, will identify the authors and works mentioned in the document and localize the books in Parisian and French libraries. Entrusted with the rubric Rabbini Hebraeorum, I quickly realized that I needed to work simultaneously on the catalogue and the dispersion of the library of the Collège. This back and forth process led to the discovery of the 1529 Bomberg Ashkenazic Siddur.
\end{abstract}

\section{Keywords}

Tabula - Collège de Sorbonne - early Hebrew printed books - Daniel Bomberg - Siddur Ashkenazi - François Guillebon - Christian Hebraists

Hebrew studies underwent a revival in the Christian world during the Renaissance. Humanist scholars developed a deep interest in the Hebrew language and in Jewish texts, especially the Hebrew Bible. As indicated by their old catalogues, ${ }^{1}$ with the expansion of Hebrew printing, libraries began to acquire Hebrew books as well, indeed many more than the few names of Christian Hebraists known to us would suggest. A document of several folios, entitled Tabula in universum indicans libros singularum disciplinarum has recently attracted renewed interest. Dated to the 17th century by two historians of Parisian libraries, Alfred Franklin and Auguste Molinier, ${ }^{2}$ it seems to reflect the state of knowledge that prevailed at the Collège de Sorbonne in the mid-16th century. A project, directed by Gilbert Fournier, who believes this document was produced before 1550, aims to identify the authors and the works mentioned in the document and to localize the

\footnotetext{
${ }^{1}$ See notably S.G. Burnett, Christian Hebraism in the Reformation Era (1500-1660): Authors, Books, and the Transmission of Jewish Learning (Leiden/Boston 2012). One example is the first printed catalogue of the Bodleian Library: T. James, Catalogus librorum bibliothecae publicae quam vir ornatissimus Thomas Bodleius eques auratus in Academia Oxoniensi nuper instituit (Oxford 1605). See p. 24: Hebrew Biblical exegesis are listed among Latin Biblical exegesis; p. 49: Hebrew books with a title in Hebrew characters.

${ }^{2}$ A. Franklin, Les anciennes bibliothèques de Paris I (Paris 1867), 301; A. Molinier, Catalogue des manuscrits de la Bibliothèque Mazarine III (Paris 1890) 280.
} 
surviving volumes in the different libraries in Paris and in France. ${ }^{3}$ One of the rubrics in this catalogue, entitled Rabbini Hebraeorum, is entirely devoted to Hebrew books and alia. It raises specific difficulties, in particular with regard to the identification of texts, and some of the hypotheses require the localization of the volumes to be validated, as shall be demonstrated in this paper. Approaching the problem from the opposite direction, the systematic examination of the collection in some Parisian libraries has made it possible to solve some of the puzzles. Indeed, research on the rubric Rabbini Hebraeorum led to the discovery of the only complete copy of a siddur, printed by Daniel Bomberg, in 1529 in Venice, which will be presented in the last part of this article.

\section{The New Library of the Collège de Sorbonne (Late 15th Century) and the Tabula}

The first library of the Sorbonne 4 was founded by Robert de Sorbon, who started compiling its catalogue. In 1289, it contained 1,017 volumes. Numerous legacies allowed the collection to grow and the catalogue of 1338 lists more than 1,700 books. Because of the disrepair of the premises and the risk of collapse, the Collège de Sorbonne planned the construction of a new library around 1481, the different stages of which can be followed thanks to the register of the deliberations of the council. 5

In 1489 , the college paid the sum of 45 pounds for the purchase of desks, in or on which the books were stored. Claude Héméré (c. 1580-1650), librarian and historian of the Collège, specifies that the building consisted of a gallery 40 'steps' long and 12 'steps' wide $(40 \times 12 \mathrm{~m})$ and that the books were chained on 28 desks measuring 5 feet $(1.60 \mathrm{~m})$ in height. Little information concerning the composition of the collection has come down to us, apart from an unpublished document, which probably reflects the disposition of the works in the various desks of the new library.

This document, entitled Tabula in universum indicans libros singularum disciplinarum (henceforth the Tabula), is a list of books that is extant in two witnesses: Paris, Bibliothèque Mazarine Ms 4204 (formerly 3286) and Paris, Bibliothèque de l'Arsenal Ms 1228 (formerly 6360). ${ }^{6}$ It probably dates from the middle of the 16th century because of the books listed in it. The Mazarine 'manuscript' is composed of 28 printed paper leaves ( $430 \times 323 \mathrm{~mm}$ ) glued on thicker sheets, probably to ensure their preservation - the verso most likely remained blank (see reproduction in Appendix 1). The title and table of contents are inscribed on the first folio, while the other leaves contain the list of books

\footnotetext{
${ }^{3} \mathrm{~A}$ team of nearly a dozen people has been set up and each is entrusted with a part of the catalogue.

${ }^{4}$ The latest work on the history and influence of the Collège and its libraries from the 13th century to the Renaissance is C. Angotti, G. Fournier, and D. Nebbiai, eds., Les livres des maîtres de Sorbonne: Histoire et rayonnement du collège et de ses bibliothèques du XIIIe siècle à la Renaissance (Paris 2017); new edition https://books.openedition.org/psorbonne/28921, 2019.

5 G. Fournier, 'Livre après livre,' Scriptorium 67 (2013) 184-217; R. Marichal, ed., Le livre des prieurs de Sorbonne (1435-1481): texte critique avec introduction, notes et index (Paris 1987) 233-250; see also Franklin, Les anciennes bibliothèques de Paris I, 253-255. Idem, La Sorbonne, ses origines, sa bibliothèque, les débuts de l'imprimerie à Paris et la succession de Richelieu d'après des documents inédits (Paris 1875) 92-97, which gives a faulty chronology.

${ }^{6}$ The description and the hypothesis concerning the Tabula are Fournier's, 'Livre après livre.' 207-210.
} 
copied in two columns. The Arsenal witness is also printed ${ }^{7}$ and bound in a manuscript preserving different documents related to the Collège de Sorbonne. The written space, the typescript and the page-setting are identical in the two witnesses; the Arsenal folios are bigger (477 x $361 \mathrm{~mm}$, on average) than those in the Mazarine, but the latter were probably trimmed. The Arsenal folios have regular pinholes between the two columns of text. In the middle of the folios, in the upper and lower margins, the pinholes are well marked and vary from folio to folio: sometimes they define a trapezoidal shape and sometimes a square. They correspond respectively to pin- and nail-holes. The verso of the folios was originally blank, suggesting that this copy of the Tabula may have been displayed on walls or pinned to a wooden surface (the aisle desk or a wooden revetment of the wall); the word tabula can also refer to a mural catalogue. ${ }^{8}$

There are 1542 entries in the Tabula. While Latin books predominate, Arabic, Hebrew, Greek, and even Aramaic works are represented. Each item consists at most of an author's name and a title, often reduced to its simplest expression. There is no material description of the volumes, or of the composite books, which are assigned to a single rubric even when their content could have been divided into two or more rubrics.

The Tabula has 27 rubrics grouped in seven sections: Libri theologici(17 rubrics), Libri iuris et legum (2 rubrics), Libri medicinae (1 rubric), Libri historiarum (2 rubrics), Libri matheseos (1 rubric), Libri philosophici (2 rubrics) et Libri rhetorici et grammatici (2 rubrics).

Theology is the predominant category in the Tabula: the Bible, its tools, glosses and biblical commentaries occupy eight rubrics, to which can be added that of the Rabbini Hebraeorum. The Tabula is noteworthy for the importance it accorded to a generation of authors who died in the middle of the 16th century and who were known to be humanists, such as Clément Marot (1544), Beatus Rhenanus (1547), Martin Luther (1547), and Sebastian Münster (1552).

According to Fournier, three elements suggest that the Tabula should be regarded as a geographical map of the library of the Collège de Sorbonne: some areas of knowledge are distributed under two different rubrics, a fact that overrides a purely intellectual classification; the Tabula states (f. [a]1r) that it describes the suggestus (arrangement) of the content of the library - Primo Suggestu continentur Glosae in biblia, Lyr. [...], etc (In the first grouping are contained the Glosses on the bible); finally, the number of rubrics in the Tabula coincides almost exactly with the number of desks specified by Héméré. The Tabula contains 27 rubrics while Héméré speaks of 28 desks, marked by the letters of the alphabet and filled with books that were chained. As a final point, the physical description

\footnotetext{
${ }^{7}$ At Michel de Vascosan's press (Paris), as demonstrated by Yann Sordet (workshop June 19, 2017). Although both witnesses are printed, they include handwritten additions and are classified among manuscripts.

8 The name tabula is attested in the mural catalogue of the Faculty of Arts of the University of Cologne (1474): Tabula continens libros facultis arcium [...]. See Fournier, 'Livre après livre,' 211 n. 158. Fournier also suggests that this list was handed to new residents when they arrived at the Collège de Sorbonne. Some would keep it for easy reference, others would display it on the walls of their room. A third copy is mentioned in Conrad Simmler's Bibliotheca. Thanks to Gilbert Fournier who shared this information with our team while preparing an article entitled 'La Bibliotheca de Conrad Simmler (Zurich, Christophe Froschauer, 1574) et ses sources. Le catalogue du Collège de Sorbonne'.
} 
of the two Tabula witnesses - both printed ${ }^{9}$ only on one side of the leaf, and one of them bearing pin-holes for posting - corroborates Fournier's hypothesis. It is surely a geographical map of the library.

\section{An Amazing List: Rabbini Hebraeorum}

The rubric Rabbini Hebraeorum (Appendix 1), which is the ninth rubric of the section Libri theologici, brings together texts from the Jewish tradition as well as various reference works that provide access to Hebrew and to the interpretation of the Bible. It consists of 66 entries organized according to a precise order that can be found more or less in 19th-century catalogues.

- The Hebrew Bible, the bilingual Hebrew-Latin Pentateuch, with or without commentary, a Hebrew concordance, the Pentateuch accompanied by the Targum, followed by various Biblical exegetical works on the Pentateuch, the Prophets and finally, Hagiographa (entries 1-16).

- Talmudic literature: the Jerusalem Talmud (entry 17) and the Babylonian Talmud (entries 18-25. As well known, the first complete printed editions of the two Talmuds are the work of Daniel Bomberg (Venice). He published the 37 treatises of the Babylonian Talmud in 12 volumes between 1520 and 1523, while The Jerusalem Talmud was printed in 1524.

- Halakhic (rabbinic law) literature, which stems from Talmudic literature: books of commandments, responsa, and the works of Maimonides and Isaac ben Jacob Alfasi's (entries 26-40).

- Jewish philosophical texts and a prayer book (entries 41-46).

- The last part consists mainly of books in which the Renaissance humanists were interested: texts of Christian Kabbalah, as well as polemical texts, and Hebrew and Latin didactic tools for the teaching and study of the Hebrew language and the interpretation of the Bible (entries 47-66).

\section{Uncertain Identifications}

Some of the entries in the Tabula include the author's name and a short title that is sufficiently clear to allow the identification of the texts in question without difficulty. It becomes more problematic when there is no author's name or if the title is sibylline. For example, nos. 31 and 32 (Primum volumen Maimonei, Secundum volumen Maimonei) can refer to the Mishneh Torah or to Maimonides's Guide for the perplexed. In this particular case, the choice is suggested by the internal organization of the rubric, since texts dealing with the same subject are grouped together. Primum volumen Maimonei, Secundum volumen Maimonei are followed by four items that belong to the same collection, Liber

\footnotetext{
${ }^{9}$ Although they are preserved among the collection of manuscripts.
} 
magnus Alphasi, Secunda pars Alphasi, Tertia pars Alphasi and Introductiones prima secunda \& tertia (nos. 33, 34, 35, and 36). These entries definitely refer to Sefer rav Alfas, the halakhic compendium of Isaac ben Jacob from Fez (1013-1103) based on the Babylonian Talmud. ${ }^{10}$ Therefore, nos. 31 and 32 can only be a halakhic text or a Talmudic exegesis and not a philosophical text. Hence, these books are probably Moses ben Maimon's (Maimonides) Mishneh Torah, printed in two volumes in [Venice, Daniel Bomberg, 284], 1524.11 On the title page, the name of the author Maimoni (myymwny) ${ }^{12}$ appears in large sized block letters, while the title Mishneh Torah is to be found in the third line of the colophon, printed in semi-cursive letters and located on the title page. This fact probably explains the wording of the Tabula entry, Primum volumen Maimonei and Secundum volumen Maimonei.

Other entries are more complex.

No 39. Liber dedicationis sive initiationis rabbi Aaron, immediately calls to mind Sefer ha-Hinukh. The Latin translation reflects the root het-nun-khaf, which means both 'to educate' and 'to inaugurate,' wherefore the noun hinukh can be translated by initiatio or dedicatio. The identification of this entry marked a turning point in this research on the rubric Rabbini Hebraeorum. Indeed, the Sefer ha-Hinukh is anonymous, and the Venice edition dated 1523 is the only one that gives the name of an author - Rabbi Aaron. The book, bearing the stamp of the Collège de Sorbonne, was easily located in the Bibliothèque Mazarine (Bibliothèque Mazarine, $4^{\circ} \mathrm{A}$ 13686). This finding led to the formulation of two hypotheses: the books mentioned in the Tabula (Rabbini Hebraeorum) are probably early printed books and not manuscripts, and secondly, some of these books, in fact a great majority, are extant and preserved in the Bibliothèque Mazarine. This is true for this rubric only. ${ }^{13}$

Their presence in the Bibliothèque Mazarine is a consequence of the decree of April 5, 1792 abolishing the Collège de Sorbonne. When the library was dismantled in 1795, almost all the manuscripts, about 2,000 volumes, went to the Bibliothèque nationale de France, while the printed books were distributed among various public libraries. ${ }^{14}$ If

\footnotetext{
10 The first Venetian edition by Daniel Bomberg dates from 1521-1522, but there existed an earlier one, printed in Constantinople 1509.

11 There are at least five incunabula editions of Mishneh Torah (Rome c. 1473-1475; Portugal c. 1480; Soncino 1490; Spain c. 1490; Spain or Portugal b. 1492) and an earlier 16th-century edition in two volumes, printed in Constantinople 1509.

${ }^{12}$ In the colophon on the same page, the author's name is R. Moses ben ha-Dayan R. Maimon (vol. 1) or haRaMBaM (vol. 2).

${ }^{13}$ In the mathematics section, for example, which contains over 80 entries, one third are manuscripts and two thirds are printed books. Most of the manuscripts are today kept in the manuscript department of the Bibliothèque nationale de France; most of the printed books are in the Bibliothèque Mazarine, although a few are in the Conservatoire National des Arts et Métiers library. Research work in progress, carried out by Christine Bénévent, Alissar Levy, Laure Miolo, and Isabelle Pantin. See also A. Levy, 'Du quadrivium aux disciplinae mathematicae: histoire éditoriale d'un champ disciplinaire en mutation (1480-1550). Une recherche de bibliographie matérielle et d'histoire sociale du livre à Paris au XVIe siècle '(PhD thesis, École nationale des chartes 2020) 252-261.

14 There is an inventory of printed books from the Sorbonne library which dates from the 18th century and which may give us additional information for this catalogue: Inventaire des livres imprimés de la grande bibliothèque de Sorbonne, which was done and written by M. Foulques, Chaplain of Sorbonne, as mentioned
} 
indeed a large number of the early printed books in Hebrew from the Collège de Sorbonne were transferred to the Bibliothèque Mazarine, this research must give priority to the Mazarine's collection. ${ }^{15}$ This led to a second discovery, which was decisive for the identification and localization of numerous volumes.

Many of the books bear the ex libris or ex dono of François Guillebon. Research on François Guillebon's collection was first undertaken by Denise Gid ${ }^{16}$ in 2006, but its reconstruction remains largely incomplete and many volumes that belonged to him have yet to be identified.

Guillebon was appointed rector of the Collège de Sorbonne on March 24, 1523. He was then made prefect of the library from 1524 to 1526, and became prior of the Sorbonne in 1526. He died around 1534 and the Collège de Sorbonne inherited his books. The books that belonged to Guillebon were therefore in the library of the Collège de Sorbonne when the Tabula was written. A copy of Maimonides's Mishneh Torah, printed in Venice by Daniel Bomberg was among Guillebon's books. The title page of the first volume bears the following note: Ex dono Francisci Guillebon doctoris theologi socii quondam Sorbonici (Bibliothèque Mazarine, $2^{\circ}$ 2328).

Another important clue is the presence of traces of chaining at the back of the book, since the books were chained to the desks from $1289 / 1290$ to 1615.17 This is the case in the Sefer ha-Hinukh and in the two volumes of the Mishneh Torah.

This fact proved to be important since it led to the assumption that, although only eight tractates of the Babylonian Talmud are mentioned in the Tabula, Guillebon had acquired the entire collection. Indeed, the Bibliothèque Mazarine has a copy of the Babylonian Talmud in 10 volumes (Venice, Daniel Bomberg) originating from the library of the Collège de Sorbonne (Mazarine $2^{\circ} 2322 \mathrm{~A}-\mathrm{J}$ ), in which the tractates bearing Guillebon's ex dono correspond to the titles mentioned in the Tabula. Based on Guillebon's ex dono, usually inscribed on the first title page of the volume, and the chain traces that attest to the presence of these tractates in the Collège de Sorbonne library, the order in which the volumes were bound most certainly corresponded to the order in which the tractates were printed and integrated into Guillebon's collection.

In the 17th century, the books were bound from scratch, but the order adopted is a non-logical order, which only proves that the bookbinder or the person who prepared the volumes did not know Hebrew. For example, the entry De sabbato, rabbi Salomon, rabbi Aser refers to BT Shabbath [Venice, Daniel Bomberg, 280] with the details inscribed on the title page, ex dono Francisci Guillebo[n] [...] theologi [...] sorbonici (Mazarine $2^{\circ} 2322$

\footnotetext{
on the flyleaf (Mazarine Ms 4122, previously Ms 3166). See Franklin, Les anciennes bibliothèques de Paris I, 301 and Molinier, Catalogue des manuscrits de la Bibliothèque Mazarine III, 281.

15 The Hebrew books of the Bibliothèque Mazarine were recently catalogued by Bertram Schwarzbach (2013). Most of the descriptions are online (www.bibliotheque-mazarine.fr/fr/catalogues) but the printed catalogue has not yet been published.

${ }^{16}$ D. Gid, 'La bibliothèque de François Guillebon prieur de Sorbonne,' in A. De Coster and C. Sorgeloos, eds., Bibliophilies et reliures: Mélanges offerts à Michel Wittock (Bruxelles 2006) 256-263.

${ }^{17}$ For the interpretation and dating of the chain marks, see C. Angotti,' Les manuscrits du collège de Sorbonne: une enquête codicologique,' in Angotti, Fournier and Nebbiai, eds., Les livres des maîtres de Sorbonne, 245-341, esp. 306-309; Franklin, La Sorbonne, ses origines, sa bibliothèques, 131: in 1615, the decision was taken to stop chaining volumes to tables (cited by Angotti).
} 
A-3). This tractate is the third of the volume which also contains Mishnah Zera im (Mazarine $2^{\circ} 2322 \mathrm{~A}-1$ ) and BT Berakhot (Mazarine $2^{\circ} 2322 \mathrm{~A}-2$ ). There are no traces of chaining in this volume.

The initial assumption that Guillebon had probably acquired all the tractates of the Babylonian Talmud, was confirmed by Alissar Levy, ${ }^{18}$ who found evidence of this: [In 1527], Franciscus Guillebon Sorbonicus, qui bibliothecam Sorbonicam multis libris praesertim hebraicis et Talmud integro auxit. ${ }^{19}$ Since Guillebon bequeathed his Hebrew books with the Talmud before all the tractates were printed, one can suppose that he had paid in advance for the whole set to Daniel Bomberg. ${ }^{20}$

\section{A Complete Copy of the Bomberg Ashkenazic Mahzor}

Even if a Tabula entry makes it possible to know what type of work it refers to, the book can only be formally identified by its localization in a library and on condition that there is sufficient evidence to affirm that it was in the collection of the Collège de Sorbonne. One of the entries in the Tabula is quite puzzling. It is no. 45: Breviarium Iudaeorum Germaniae, Vives de Concordia, which seems to refer to two different items.

The first part clearly refers to an Ashkenazic prayer book (siddur) arguably printed in the early 16 th century.

The famous bibliographer Moritz Steinschneider was the first to mention, in his catalogue of Hebrew printed books in the Bodleian Library, Daniel Bomberg's edition of a prayer book that was no longer extant, printed in Venice in 1529 (Appendix 2, entry 2070). ${ }^{21}$ He relies on the 1549 edition (Appendix 3, entry 2080) which appears to be a reprint of a previous edition, as mentioned on the title page. ${ }^{22}$

Seven years later, Joseph Zedner (Appendix 4) described, in his catalogue of Hebrew books in the Library of the British Museum, ${ }^{23}$ a book printed on vellum, in-16 ${ }^{\circ}$, with 186 leaves without pagination. The book is not complete and has no title page ('imperfect, wanting leaves $\left.1-8,49,56^{\prime}\right)$. He then suggests dating it to 1529 with a question mark, without giving any explanation for his assumption, but he was probably influenced by Steinschneider's work: '[Venice, 1529?]'.

The next mention of an early edition of an Ashkenazic prayer book appears in Abraham Habermann's booklet on Daniel Bomberg's printing house (Appendix 5). ${ }^{24}$ Habermann

\footnotetext{
18 See Levy, 'Du quadrivium aux disciplinae mathematicae,' 248-249.

${ }^{19}$ E. Richer, Historia Academiae Parisiensis, Bibliothèque nationale de France, Ms. 9945, fol. 389, dating from the 17th century quoted in French by C. Desmaze, P. Ramus: Professeur au collège de France (Paris 1864) 35-36.

2022 ducatis, according to C. Gessner, Pandectarum, sive, partitionum universalium Conradi Gesneri Tigurini, medici et philosophiae professoris, libri XXI (Zurich 1548) 42v.

21 M. Steinschneider, Catalogus Librorum Hebraeorum in Bibliotheca Bodleiana (Berlin 1852-1860), no. 2070: [Ap. Bomberg, per C. Adelkind, qui ejus mentionem facit in ed. 1549].

22 Steinschneider, Catalogus, no. 2080: [In tit. "viel hübscher wenn unsre vorige vor 20 Jahren, gedruckt mit mäncherlei mehr drin” (i.e. ec. I. 20 annos antea), per Corn. Adelkind Adar (f. 387) ...].

${ }^{23} \mathrm{~J}$. Zedner, Catalogue of the Hebrew Books in the Library of the British Museum (London 1867) 458.

${ }^{24}$ A.M. Habermann, Ha-madpis Daniel Bomberg (Safed 1978) 66, no. 146.
} 
seems to follow Zedner's description: in the list of the numerous Hebrew editions by Bomberg, he includes a prayer book dated to 1529 , with a question mark. According to him, the book is sized $16^{\circ}$ and has 186 pages. He adds that he refers to the volume in the collection of Israel Mehlman and cites Steinschneider 2070 as a bibliographical reference. He clearly links the description of an extant lacunary prayer book to Steinschneider's hypothesis. Zedner and Habermann appear to be referring to the same book, which is incomplete and has 186 folios and no title page. Zedner lists the pages that are lacking, Habermann tells us where the book was when he wrote his history of the printing house. ${ }^{25}$

In 1984, Itzhak Yudlov, who wrote a catalogue of the Israel Mehlman Collection, describes the same lacunary prayer book (Appendix 6: $130 \mathrm{~mm}, 186$ leaves). ${ }^{26} \mathrm{He}$ dates it to 1520 and makes it clear that this siddur is not to be confused with Steinschneider's siddur: 'eyno zeheh le-siddur minhag Ashkenaz 289 Steinschneider 2080 // Steinschneider 2070.' According to Yudlov, there would have been two Ashkenazic prayer books, one dated 1520 and the other 1529. Confusion seems nevertheless to prevail, especially since Yudlov himself also quotes Habermann who dates this prayer book to 1529 , with a question mark.

In the Thesaurus of the Hebrew book,,27 Vinograd (Appendix 7) mentions a 'Siddur minhag Ashkenaz which he dates to 1520, quoting the opinion and the description of Yudlov. Nevertheless, Vinograd also quotes the catalogues of Steinschneider and of Zedner, both of whom mention an edition dating from 1529.28 In a supplementary entry (Appendix 8), giving the year 1529 but without number as if it never existed, Vinograd mentions a 'Siddur tefillot minhag Ashkenaz' and makes reference to the previous description (33, appendix 7).

More recently, Marvin Heller ${ }^{29}$ does not mention the prayer book in his work on 16thcentury publications in Hebrew. The Merhav catalogue of the National Library of Israel mentions this lacunary 'Siddur tefillot: minhag Ashkenaz,'30 also referring to Yudlov as a bibliographical reference and dates it to 1529.

The discrepancy in dates is surprising. Vinograd, as well as the Merhav catalogue both describe a unique incomplete witness without title page. Even though they both refer to Yudlov, Vinograd gives the exact year of 1520, while the Merhav catalogue gives the exact year of 1529. Neither Vinograd, nor the National Library of Israel heeded Yudlov's cautionary remark, that there would have been two Ashkenazic prayer books, one on vellum, dated 1520 and another one dated 1529.

Is the Breviarium Iudaeorum Germaniae mentioned in the Tabula the 1520 edition or the 1529 edition?

\footnotetext{
25 It would seem to me that Mehlman bought it from the British Museum Library.

${ }^{26}$ I. Yudlov, Sefer Ginzei Israel [the Israel Mehlman Collection](Jerusalem 1984) 53, no. 204.

${ }^{27}$ Y. Vinograd, Thesaurus of the Hebrew Book II (Jerusalem 1993-1995) 243, no. 33 [Hebrew].

28 Vinograd also quotes Habermann.

29 M.J. Heller, The Sixteenth-Century Hebrew Book: An Abridged Thesaurus (Leiden 2004). The author based his research on the extant copies of the early printed books, since each of his entries has a descriptive text page and an accompanying reproduction.

${ }^{30}$ See www.nli.org.il/he/books/NNL ALEPH001744461/NLI.
} 
This work could only be identified if it were actually located in a library, but no book that possibly fits the description had been found in any library in Paris. Then a providential discovery provided the key and allowed me to solve the puzzle. Many of the items listed among the Rabbini Hebraeorum are in the Bibliothèque Mazarine, and in May $2017^{31}$ I was informed that a Hebrew book which had not been catalogued by Schwarzbach (see $n$. 15), had been found on a shelf. See Fig. 1 for its title page and Fig. 2 for the original binding.

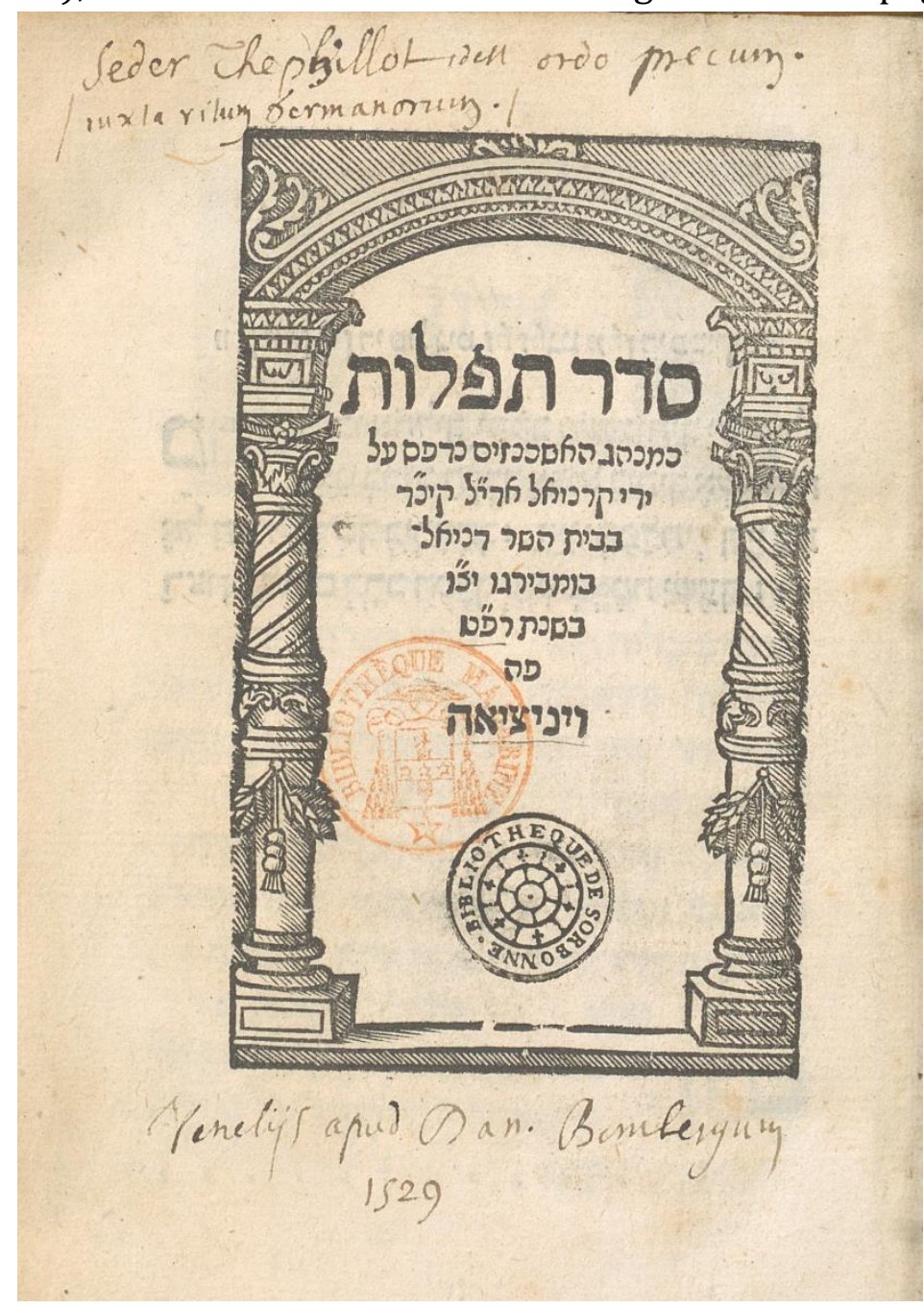

Figure 1 Seder tefillot ke-minhag ha-Ashkenazim, Venice: Daniel Bomberg, 289.

\footnotetext{
${ }^{31}$ I would like to express my special thanks to Alissar Levy, a member of the project who contributes to another part of the Tabula (Mathematical texts). She was then studying at the École des chartes and had an internship at the Bibliothèque Mazarine when she found the book.
} 


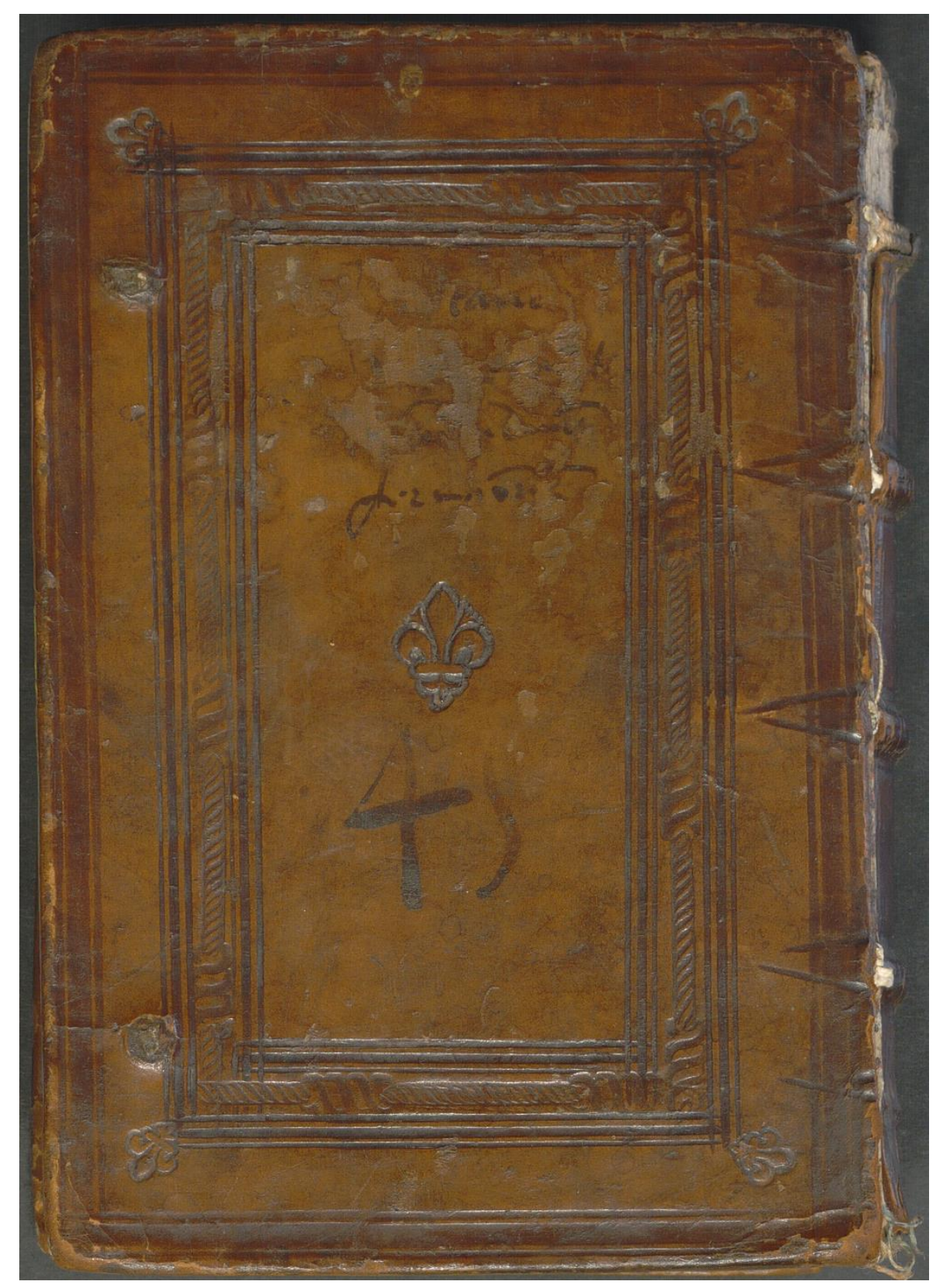

Figure 2 Original binding of Bomberg's Seder tefillot

The book (Mazarine $8^{\circ} 49620$ [Res]), originating from the Sorbonne library (stamp), is in perfect condition and is probably the only extant complete copy. It has retained its original 16th-century binding with traces of chaining, which attests to its presence in the Collège de Sorbonne library before 1615, and it still bears no. 45 inscribed on the upper board. The title on the first page is סדר תפלות כמנהג האשכנזים Seder tefillot ke-minhag haAshkenazim, and it was published by Cornelius Adelkind in 289 [1529], at Daniel Bomberg's press. It is printed in $8^{\circ}(153 \times 103 \mathrm{~mm})$ on paper and consists of 36 quires of 
8 sheets, i.e. 288 folios. It includes everyday prayers but also the additions for the festivals and the special shabbathoth. The indications for the devotee are written in Yiddish. ${ }^{32}$

In the 'Bomberg catalogue,' copied in his Pandectarum ${ }^{33}$ (fol. 41v-42v) and generally dated to $1541,{ }^{34}$ the humanist Conrad Gesner recorded a book entitled Sidurim $e$ Germania (no. 7). This item could correspond to the edition found in the Bibliothèque Mazarine and would have cost 'libra 1. solidis 11.' Once again, Steinschneider was right: a Siddur Ashkenazi was indeed printed by Bomberg in 1529.

The mystery is not completely solved for entry no. 45 Breviarium Iudaeorum Germaniae, Vives de Concordia. It cannot refer to a composite volume, because the prayer book has its own binding and was therefore not bound with another work. No Hebrew book corresponds to the description Vives de Concordia. The only option is a well-known work, Joannis Ludovici Vivis Valentini de Concordiâ et discordiâ in humano genere libri quatuor. ${ }^{35}$

A search in the various catalogues of the Parisian libraries led me to the Bibliothèque de l'Arsenal, which has two copies of this text. One of them (8-S-3214 (1)), printed in Bruges in 1529, bears chain marks which leads me to believe that this volume was in the Collège de Sorbonne library. Its size $(170 \times 110 \mathrm{~mm})$ corresponds to that of the prayer book. We must therefore assume that, for unknown reasons, these two very different volumes were chained together to the desk containing the Rabbini Hebraeorum.

\section{Conclusion}

The discovery of this prayer book is important, because it will make available to the general public a copy of the Bomberg 1529 edition (digitization in progress), the only traces of which were in the 1549 edition. This work once again confirms Steinschneider's conviction that he had spotted an important mention, which led him to create a theoretical entry in his catalogue. Beyond this single result, much research on the Rabbini Hebraeorum remains to be done. The intellectual life of François Guillebon and his relationship to the Hebrew books need to be studied in greater depth. Although never mentioned as a Hebraist, 36 Guillebon seems to have taken a very close interest in the publications of Daniel Bomberg. It will also be necessary to determine how the rest of the collection (which includes books acquired after Guillebon's death) was constituted. A

\footnotetext{
32 Fol. 1v: ווען מאן אין די שול גיט זא זאגט מאן די פסוקים (When one enters the synagogue, one says the following verses).

33 Gessner, Pandectarum.

${ }^{34}$ A. Freiman, 'Daniel Bomberg's Bücher-Verzeichnis', Zeitschrif für hebraïsche Bibliographie 10 (1906) 3842, esp. 38: 'Die Liste ist nach 1541 abgeschlossen, da Elia Levita's Tischbi noch aufgenommen ist.'

35 Juan Luis Vives was a Spanish humanist and educational theorist and one of the most influential advocates of humanistic learning in the early 16th century. He taught at the Collegium Trilingue in Louvain, a humanist foundation based on Erasmian educational principles. See L. Casini, 'Juan Luis Vives [Joannes Ludovicus Vives],' in E.N. Zalta, ed., The Stanford Encyclopedia of Philosophy (Spring 2017 edition). https://plato.stanford.edu/archives/spr2017/entries/vives/.

${ }^{36}$ Burnett, Christian Hebraism, 331-344: the name Guillebon is not mentioned in the index.
} 
physical examination of the volumes that I believe come from the Collège de Sorbonne library will surely yield further, interesting results. 


\section{Appendices}

1. Tabula in universum indicans libros singularum disciplinarum, Rubric I, 9. Paris, Bibliothèque Mazarine Ms 4204

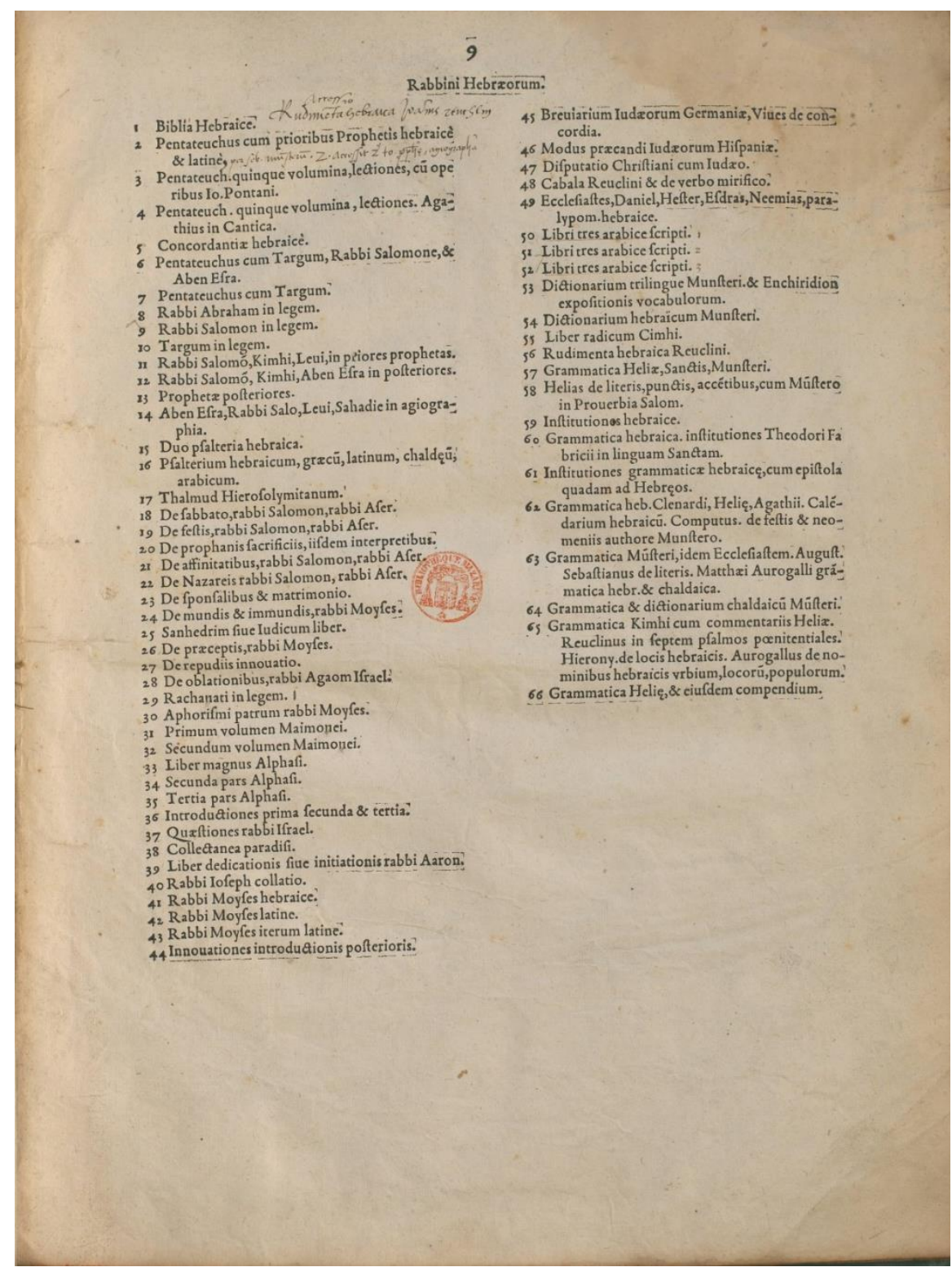

2. Steinschneider, 1852-1860, vol. 1, p. 306
2070] - rit. Germ.
8. Ven. 1529

[Ap. Bomberg, per C. Adelkind, qui ejus mentionem facit in ed. 1549 N. 2080.]

\section{Steinschneider, 1852-1860, vol. 1, p. 308}

2080] - rit. Germ., Haggada, Abot, Hoschaanot, Maaribim, Paraschijjot, Jozerot (f. 145-61) inclusis in 4 Paraschijjot, Hylnus unitatis. Ed. Repet. auctior 8. Ven. 1549. [In tit. "viel hübscher wenn unsre vorige vor 20 Jahren, gedruckt mit mäncherlei mehr drin" (i.e. 
auctior ed. I. 20 annos antea), per Corn. Adelkind mense Adar (f. 387). Index et Hymnus usque ad f. 408. Ed. rarissima.]

4. Zedner, 1867, p. 458

Another edition. On vellum [Venice, 1529?] $16^{\circ}$.

186 leaves without pagination. Imperfect, wanting leaves 1-8, 49, 56.

5. Habermann, 1978, p. 66.

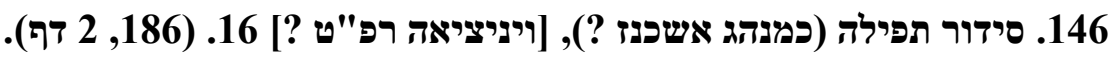
עפ פרשיות מכל השנה, ובסופו הגדה של פסחי (146. דף קכ"ח נשאר ריק באמצע הפיוט "אלהים בישראל גדול נודעת" (דוידסון 4685). ב"במה מדליקין, מנוקדת

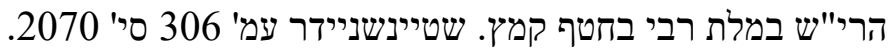

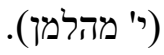

6. Yudlov, 1984, p. 53.

204 [סדור מנהג אשכנז]. [ויניציאה, דפוס בומבירה, ר"פ לערים לערד]. 13 ס"מ ע"מ בלתי שלם: [7], נ-רכח, [40] אא- הה, רפו-רצא דף. חסר לפני [7] הדפים ניפים ואחריהם ולפים ולפני הדפים רפו-רצא ואחריהם, ועוד חסרים כ-12 זפים פזורים. התוכן: עד דף סח: תפלות לחול, ולשבת מ"נשמת" ואילך. סח: חנוכה. פורים. ט באב. - ע : פרשיות. סליחות לבה"ב.

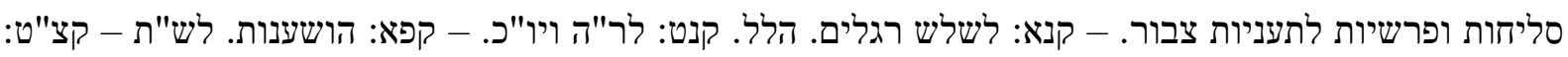

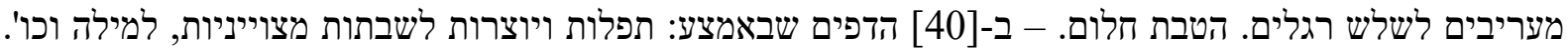

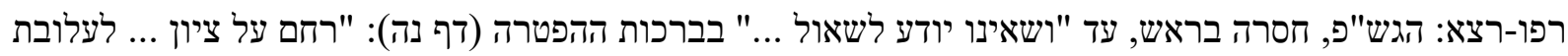

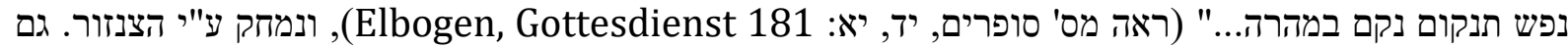

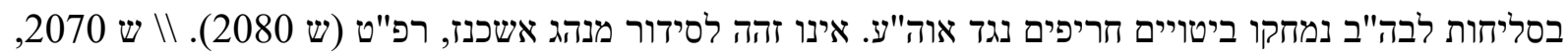

הברמן בומבירגי 146 ע"פ ע"מ. א"מ 691

7. Vinograd II, 1993-1995, p. 243

33 [סידור מנהג אשכנז] ויניציאה, [דניאל בומבירגי], [ר"ף] [186, 2] דף, 13 ס"מ. שט 2070, צד 458 רושמים שנת 1529. 0], הב 146, גי 204

8. Vinograd II, 1993-1995, p. 246 (without number, after 139)

סידור תפילות מנהג אשכנז [ייניציאה], [1529], ראה: שנת ר"ף מנדגור 